\title{
Side effect profile of 55 Heart Transplant patients - an Indian study
}

\author{
Ratnagiri Ravi Kumar* and Prabhat Dutta \\ Department of Heart and Lung Transplantation, Gleneagles Global Hospital Chennai, India
}

Submission: January 18, 2019; Published: February 26, 2019

*Corresponding author: R Ravi Kumar, Department of Heart and Lung Transplantation. Gleneagles Global Hospital, 439, Cheran Nagar, Chennai, India

Keywords: Heart transplantation; Right heart failure; Milrinone or Nitric oxide; Vasodilator testing; Injection Basiliximab; Steriod Wysolone;

Anti depressents; Leucopenia; VanGancyclovir; Mycophenolate

\section{Introduction}

We Studied 55 patients undergoing Heart Transplant in our center between 2017-2018, for their side effect profile and clinical course therafter.

\section{Materials and Methods}

Age range 21-66 yrs. There were 45 males and 10 females. All patients were NYHA class 3 and above, 25 were in NYHA class 4 (Severe CHF). 4 were on preop ECMO or Ventricular Assist device (VAD) support. PVR range was from 0.5 to 6.9 wood units (prior to Vasodilator testing by Injection Milrinone or Nitric oxide). Patients were followed up for a period of 1 year after Heart Transplantation [1].

\section{Results and analysis}

Just before Heart Transplant, all patients received 10-20 mg of Induction with Injection Basiliximab (dose as per body weight and general condition) single dose. Second dose of Basiliximab was Given selectively in 15 patients. Post op immunosuppression regimen was Tacrolimus in 54, Tacrolimus (low dose with a target of $2-3 \mathrm{ng} / \mathrm{ml}$ ) PLUS Everolimus $0.25 \mathrm{mg}$ bid in 5 patients, Mycophenolate in all patients. Steriod Wysolone was given for 6 months in 45 patients and in the rest upto 1 year. Post operatively in 38 patient's creatinine levels Normalized by day 5, allowing initiation of Tacrolimus. While in other 12 patients Tacrolimus could be started only at day 10 with NO Ill effects or rejection episodes. In all patient's CD 25 level was checked on day 3 and second dose of basiliximab given only if CD 25 more than 3\%. Post op no patient had sustained neutropenia. Only 2 patient needed therapy for Azotemia with post-operative dialysis. 3 patients died of Severe RF and sepsis [2].
15 patients $(27 \%)$ has new onset Diarrhoea in the First year after Transplant of whom 4(7\%) were found to have CMV antigen Positive - these resolved with IV Gancyclovir in 3. One had clostridium difficile positive diarrhoea-treated with IV Vancomycin Plus Metronidazole. In 7 patients diarrhoea resolved with termination of Mycophenolate and other 4 had E-coli or Salmonella diarrhea resolved with Oral antibiotics. One Patients had extensive Herpes Zoster which resolved with anti-Viral drug Acyclovir. One Patient had Hepatic Mucormycosis Tretaed with Amphoterecin [3].

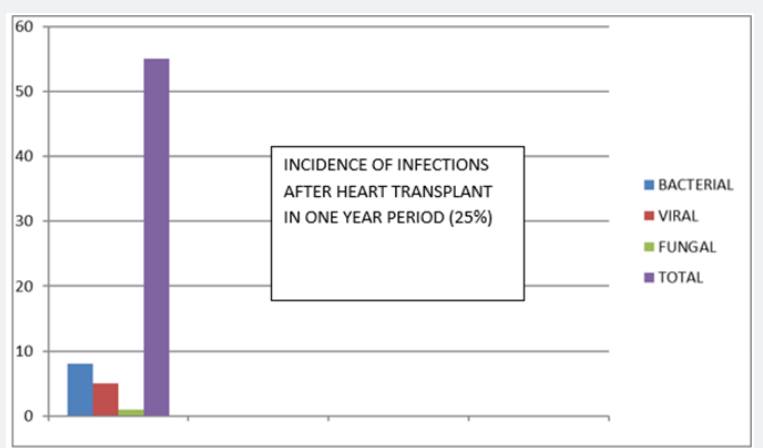

Figure 1: Different Infections with Incidence Out of Total Heart Transplant Cases $(\mathrm{N}=55)$.

$12(22 \%)$ patients all over the age of 40 had sustained Tremors - which resolved in all with beta blockers or Neuro Vitamins. 5 had severe tremors - which resolved after changing from tacrolimus to Cyclosporine. 10 (18\%) patients had severe headache treated with tricyclic Anti depressents and 5 needs change to cyclosporine. $10(18 \%)$ patients had episodes of Leucopenia, 8 which resolved 
after temporary stoppage of VanGancyclovir and reduced dose of Mycophenolate. 2 patients need SC G-CSF. Therapy [4,5] (Figure $1 \& 2)$.

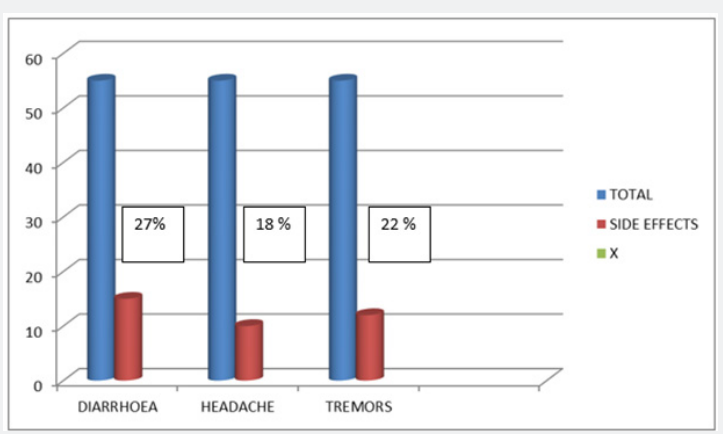

Figure 2: Incidence of various side effects after Heart Transplants.

\section{Conclusion}

$30 \%$ of Patients had persistent pulmonary Hypertension one month after heart Transplant and 15\% had persistent PAH one Year after heart Transplant. But this factor does not seem to be associated with Right heart failure or reduced survival. Above
Findings might have been positively influenced by Anti PAH drugs like Ambrisentan or Sildenefil given Pre-operatively.

\section{References}

1. Hollaran PF, Gourishankar S (2001) Principals and overview of immunosuppression. In: Norman DJ, Turka LA, eds. Primer on Transplantation. Mt Laurel, NJ: American Society of Transplantation 87-98.

2. Olivari MT, Kubo SH, Braunlin EA, Bolman RM, Ring WS (1990) Fiveyear experience with triple-drug immunosuppressive therapy in cardiac transplantation. Circulation 82(5 Suppl): IV276-280.

3. Groetzner J, Meiser BM, Schirmer J, Koglin J, vScheidt W, et al. (2001) Tacrolimus or cyclosporine for immunosuppression after cardiac transplantation: which treatment reveals more side effects during long-term follow-up? Transplant Proc 33(1-2): 1461-1464.

4. Meiser BM, Pfeiffer M, Schmidt D, Reichenspurner H, Ueberfuhr P, et al. (1999) Combination therapy with tacrolimus and mycophenolate mofetil following cardiac transplantation: importance of mycophenolic acid therapeutic drug monitoring. J Heart Lung Transplant 18(2): 143149.

5. Mehra MR, Zucker MJ, Wagoner L, Michler R, Boehmer J, et al. (2005) A multicenter, prospective, randomized, double-blind trial of basiliximab in heart transplantation. J Heart Lung Transplant 24(9): 1297-1304.

\begin{tabular}{l} 
Your next submission with Juniper Publishers \\
will reach you the below assets \\
- Quality Editorial service \\
- Swift Peer Review \\
- Reprints availability \\
- E-prints Service \\
- Manuscript Podcast for convenient understanding \\
- Global attainment for your research \\
- Manuscript accessibility in different formats \\
( Pdf, E-pub, Full Text, Audio) \\
- Unceasing customer service \\
Track the below URL for one-step submission \\
https://juniperpublishers.com/online-submission.php \\
\hline
\end{tabular}

